\title{
CORRELATION BETWEEN UMBILICAL ARTERIAL BLOOD GAS PARAMETERS AND APGAR SCORE IN HIGH-RISK PREGNANCY
}

\author{
Seshanganur Sitaraman Kumaran', Mullainathan Sucindar², Subramani Ashok ${ }^{3}$ \\ ${ }^{1}$ Assistant Professor, Department of Paediatrics, Sri Lakshmi Narayana Institute of Medical Sciences (SLIMS), Puducherry. \\ ${ }^{2}$ Assistant Professor, Department of Paediatrics, Sri Lakshmi Narayana Institute of Medical Sciences (SLIMS), Puducherry. \\ ${ }^{3}$ Senior Assistant Surgeon, Department of Paediatrics, Government Hospital, Kavindapadi, Erode.
}

\section{ABSTRACT}

\section{BACKGROUND}

According to literature, only few studies are available on correlation of umbilical artery blood gas parameters and Apgar score in high-risk pregnancy. Due to paucity of studies, we have done this study in South Indian population, particularly Puducherry for early and better detection of high-risk newborns with metabolic acidaemia.

The aims of this study are-

1) To compare the 1 and 5 minutes, umbilical arterial blood gas parameters between high- and low-risk pregnancies,

2) To compare the correlation between 1 minute Apgar score and umbilical arterial blood gas parameters, 5 minutes Apgar score and umbilical arterial blood gas parameters in high- and low-risk pregnancies.

\section{MATERIALS AND METHODS}

This was an analytical comparative study performed on 150 mother-foetal pairs during June 2016 to May 2017 at SLIMS, Puducherry. Apgar score at 1 and 5 minutes after birth was taken and umbilical cord blood gas analysis was done immediately after birth in both groups. Mothers who came with labour pain were divided into high and low risk, if they have had any perinatal risk factors. Other data like gestational age, birth weight, need for resuscitation and admission to the newborn ward or Neonatal Intensive Care Unit were gathered for comparison between the two groups. All the data were statistically analysed using SPSS software.

\section{RESULTS}

There were no significant differences in mean birth weight, gender and mode of delivery between high-risk and low-risk mothers.

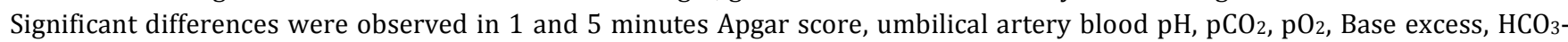
between high-risk and low-risk mother-baby pairs. According to the Spearman's Rho correlation coefficient, there were statistically significant positive correlation ( $\mathrm{p}<0.05, \mathrm{r}=0.2-0.4$ ) between 1 minute Apgar score and $\mathrm{pH}, \mathrm{pO}_{2}, \mathrm{pCO}_{2}$ and $\mathrm{Base}$ excess in high-risk pregnancy, but there was no significant correlation between Apgar score at 1 and 5 minutes and umbilical blood gas parameters in low-risk group $(\mathrm{r}<0.2, \mathrm{P}>0.05)$.

\section{CONCLUSION}

Our study highlights a correlation between 1 minute Apgar score and umbilical artery blood gas parameters in high-risk pregnancy. So we recommend assessing umbilical blood gas analysis in neonates born to high-risk mothers to detect metabolic acidaemia earlier.

\section{KEYWORDS}

Umbilical Arterial Blood Gas Parameters; Apgar Score; Metabolic Acidaemia.

HOW TO CITE THIS ARTICLE: Kumaran SS, Sucindar M, Ashok S. Correlation between umbilical arterial blood gas parameters and Apgar score in high-risk pregnancy. J. Evolution Med. Dent. Sci. 2017;6(88):6147-6152, DOI: 10.14260/jemds/2017/1335

\begin{abstract}
BACKGROUND
When oxygen supply to the foetus is significantly disrupted, tissue oxygenation deprivation develops, acids begin to accumulate and acidaemia develops. Apgar score ${ }^{1}$ has been used for assessment of asphyxia, predict neurological damage and vitality of a neonate during the first and fifth minute of life by the following clinical signs: heart rate, respiratory effort, muscle tone, reflex irritability and colour. Umbilical cord blood gas analysis was taken immediately after birth seem to be the most objective determination of the foetal metabolic condition at the time of birth. ${ }^{23,4,5}$
\end{abstract}

'Financial or Other Competing Interest': None.

Submission 15-09-2017, Peer Review 24-10-2017,

Acceptance 30-10-2017, Published 06-11-2017.

Corresponding Author:

Dr. Mullainathan Sucindar,

C- 39, Electric Lane, Block-26, Neyveli - 607803.

E-mail: dr.sucindar@gmail.com

DOI: $10.14260 /$ jemds/2017/1335
Correlation between Apgar score and umbilical artery blood gas parameters helps in better detection of high-risk newborns with metabolic acadaemia. ${ }^{6,7}$

\section{Need of Study}

We have gone through medical literature (PubMed, Google Scholar) and found paucity of studies available about correlation between umbilical arterial $\mathrm{pH}$ and Apgar score in high-risk and low-risk pregnancies. ${ }^{7}$ We to our surprise found that no Indian studies are available in the literature reporting on correlation between umbilical artery gas parameters and Apgar score at 1 and 5 minutes in high-risk and low-risk pregnancies. Due to paucity of studies in the literature, we have done this study in Indian population for early and better detection of high-risk newborns with metabolic acidaemia.

\section{Aims and Objectives}

1. To compare- 
a. 1 minute Apgar score between high- and low-risk pregnancies.

b. 5 minutes Apgar score between high- and low-risk pregnancies.

c. Umbilical arterial blood gas parameters between high- and low-risk pregnancies.

2. To compare the correlation between-

a. 1 minute Apgar score and umbilical arterial blood gas parameters in high- and low-risk pregnancies.

b. 5 minutes Apgar score and umbilical arterial blood gas parameters in high- and low-risk pregnancies.

\section{MATERIALS AND METHODS}

This was an analytical comparative study conducted at Sri Lakshmi Narayana Institute of Medical Sciences, Puducherry during June 2016 to May 2017 after approval from Ethical and Scientific Committee. Study population consisted of neonates born to mothers who were admitted with risk factors. At the time of admission, they were assigned to highor low-risk group according to whether or not they had any perinatal risk factor. High-risk pregnancy was defined as a pregnant mother who is at risk to deliver a neonate with birth asphyxia according to the definition by American Academy of Paediatrics. ${ }^{6}$ All mothers who delivered a baby with a major congenital anomaly or had intrauterine foetal death (IUFD) were excluded from the study.

\section{Sample Size}

Considering alpha error of 0.05 and power of study of $80 \%$, the sample size required to detect a correlation coefficient of 0.2 was calculated by using the following formula-

$$
\mathrm{n}=\frac{2 \mathrm{Z}^{2}(1-\alpha) / 2 \sigma}{\mathrm{d}^{2}}
$$

where $\mathrm{n}$ is the minimum sample size required from each of the population to estimate the difference between two means $\mu_{1}$ and $\mu_{2}$ with $1-\alpha$ is $95 \%$ confidence interval.

$\mathrm{Z}_{1-\alpha / 2}$ - table value from standard normal distribution corresponding to area $1-\alpha / 2$

$\sigma$ - standard deviation of a response variable (Assumed to be same in study population).

$\mathrm{d}$ - the precision required on either side of true difference $\left(\mu_{1}-\mu_{2}\right)$.

\section{Methodology}

Immediately after delivery, umbilical cords were clamped on both ends and an arterial blood sample was collected anaerobically in a pre-heparinized insulin syringe. Blood gas parameters like $\mathrm{pH}, \mathrm{pCO}_{2}, \mathrm{pO}_{2}$, Base excess and $\mathrm{HCO}_{3}$ - were measured at $37^{\circ} \mathrm{C}$ by $\mathrm{pH}$ and gas analyser. The gas analysis was done within 30 minutes after sampling. Values from the umbilical cord artery provide the most accurate information regarding foetal and newborn acid-base status. APGAR score was assessed by a paediatrician at $1^{\text {st }}$ and $5^{\text {th }}$ minute after birth. Advanced resuscitation means that a baby required positive pressure ventilation, chest compression and/or drugs administration. All resuscitated babies were transferred to neonatal intensive care unit for post resuscitation care. Foetal distress was defined by an umbilical cord $\mathrm{pH}<7.2$.

\section{Following Data were entered in the Predesigned Data Entry Form}

a. Mother's details include Age, Obstetric index and Risk factors.

b. Baby's details include Gestation, Birth weight, Apgar score at 1 and 5 minutes and Umbilical cord blood gas parameters like $\mathrm{pH}, \mathrm{pCO}_{2}, \mathrm{pO}_{2}, \mathrm{HCO}_{3}$ - and Base excess.

\section{Statistical Analysis}

IBM SPSS statistical software version 21@ was used for statistical analysis. Baseline maternal and neonatal parameters like parity, gender of the baby, mode of delivery, birth weight, risk status and Apgar score at 1 and 5 minutes were taken as explanatory parameters. Arterial blood gas parameters like $\mathrm{pH}, \mathrm{pCO}_{2}, \mathrm{pO}_{2}, \mathrm{HCO}_{3}$ - and Base excess were taken as outcome parameters. Descriptive analysis of all the explanatory and outcome parameters was done. All the categorical variables were presented in frequencies and percentages. The numerical variables were presented as mean values along with their standard deviation. The association between explanatory and outcome parameters was assessed by calculating Spearman's Rho correlation coefficient and mean differences; 95\% CI and p-value for all the parameters were assessed by using appropriate statistical tests like chi-square test or independent sample $\mathrm{T}$ test analysis. Descriptive analysis of other relevant parameters

\begin{tabular}{|c|c|c|c|c|}
\hline \multicolumn{2}{|c|}{ Variables } & $\begin{array}{c}\text { High-Risk } \\
\text { Group } \\
\text { (n= 73) }\end{array}$ & $\begin{array}{c}\text { Low-Risk } \\
\text { Group } \\
(n=77)\end{array}$ & $\begin{array}{c}\text { P- } \\
\text { Value }\end{array}$ \\
\hline \multicolumn{2}{|c|}{$\begin{array}{l}\text { Mean Birth weight of the } \\
\text { Neonates (Grams) }\end{array}$} & 2970 & 3082 & 0.089 \\
\hline \multirow{2}{*}{$\begin{array}{c}\text { Neonates } \\
\text { Gender }\end{array}$} & Male & $\begin{array}{c}39 \\
(53.4 \%) \\
\end{array}$ & $\begin{array}{c}39 \\
(50.6 \%) \\
\end{array}$ & \multirow[b]{2}{*}{0.734} \\
\hline & Female & $\begin{array}{c}34 \\
(46.6 \%)\end{array}$ & $\begin{array}{c}38 \\
(49.4 \%)\end{array}$ & \\
\hline \multirow{2}{*}{$\begin{array}{c}\text { Obstetric } \\
\text { Status }\end{array}$} & Primigravida & $31(42.5 \%)$ & $32(41.6 \%)$ & \multirow[b]{2}{*}{0.910} \\
\hline & Multigravida & $42(57.5 \%)$ & $45(58.4 \%)$ & \\
\hline \multirow{4}{*}{$\begin{array}{l}\text { Mode of } \\
\text { Delivery }\end{array}$} & NVD & $33(45.2 \%)$ & $50(64.9 \%)$ & \multirow{4}{*}{0.112} \\
\hline & LSCS & $25(34.2 \%)$ & $16(20.8 \%)$ & \\
\hline & VACUUM & $10(13.7 \%)$ & $7(9.1 \%)$ & \\
\hline & FORCEPS & $5(6.8 \%)$ & $4(5.2 \%)$ & \\
\hline \multicolumn{2}{|c|}{$\begin{array}{l}\text { Need for advanced } \\
\text { resuscitation }\end{array}$} & $5(6.8 \%)$ & $0(0 \%)$ & 0.020 \\
\hline \multicolumn{2}{|c|}{ Need for NICU admission } & $18(24.7 \%)$ & $0(0 \%)$ & $<0.001$ \\
\hline
\end{tabular}
was also presented appropriately.

\section{RESULTS}

NVD- Normal Vaginal Delivery; LSCS- Lower Segment Caesarean Section; NICU = Neonatal Intensive Care Unit

Table 1. shows statistically there was no significant difference in the demographic variables like mean birth weight and gender of the neonates as well as parity of the mother and mode of delivery between high- and low-risk pregnancy, whereas need for advanced resuscitation and 
NICU admission was present only in neonates born to highrisk pregnancy, which was statistically significant.

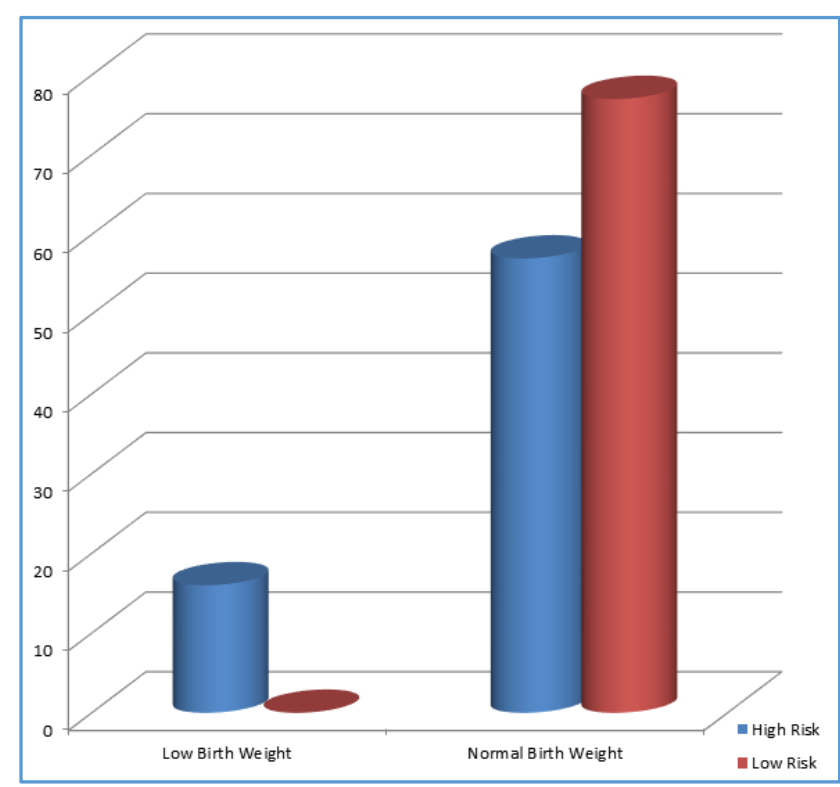

Figure 1. Low and Normal Birth Weight Babies among Highand Low-Risk Groups $(N=150)$

The proportion of low birth weight infants was $21.9 \%$ in the high-risk group, whereas all the infants in the low-risk category were having normal birth weight (Fig. 1).

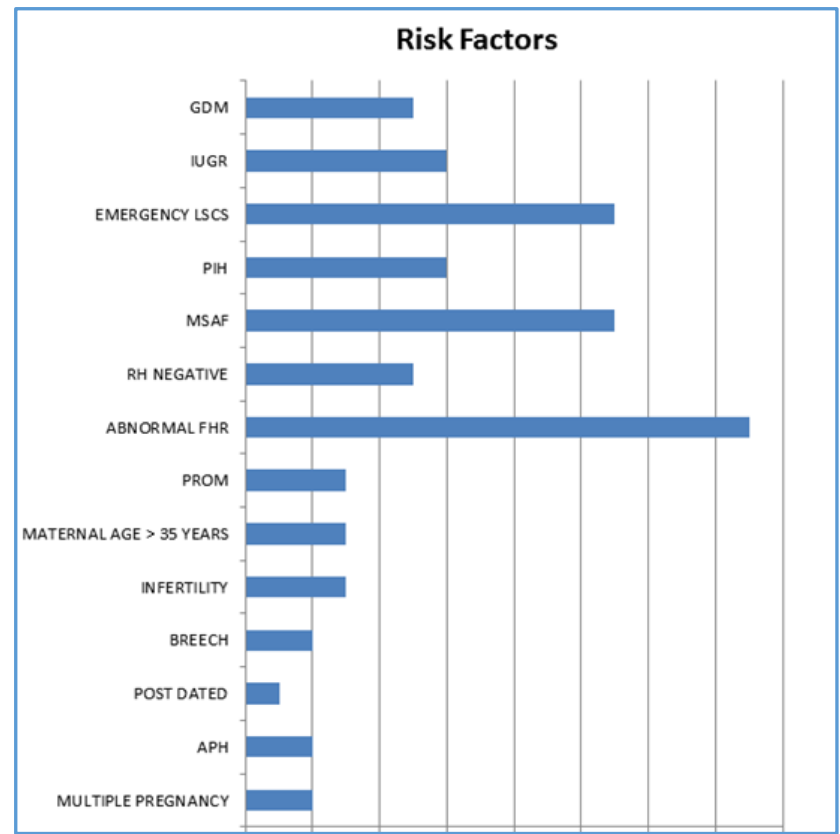

Figure 2. Frequency of High-Risk Factors in the Pregnant Women $(N=150)$

The frequency of each of the high-risk factor was presented in Fig. 2. Abnormal FHR (Foetal Heart Rate), MSAF (Meconium-Stained Amniotic Fluid) and Emergency LSCS were common high-risk factors present in our study group.

\begin{tabular}{|c|c|c|c|c|c|}
\hline \multirow{2}{*}{ Category } & \multirow{2}{*}{ Mean } & Mean & \multirow{2}{*}{ difference } & P-value & \multicolumn{2}{|c|}{$95 \%$ CI } \\
\cline { 5 - 6 } & & Lower & Higher \\
\hline High risk & 6.95 & & & \\
\hline Low risk & 7.83 & -0.886 & $<0.001$ & -0.987 & -0.785 \\
\hline \multicolumn{7}{|c|}{ Apgar at 5 Minutes } \\
\hline High risk & 8.10 & -0.982 & $<0.001$ & -1.073 & -0.891 \\
\hline Low risk & 9.08 & -08 & Minute \\
\hline
\end{tabular}

Table 2. Comparison of Apgar Score between High-Risk and Low-Risk Pregnancies $(N=150)$

The mean 1 minute Apgar score was 0.88 (95\%, CI -0.98 to -0.78 ) lesser and mean 5 minutes Apgar score was 0.98 (95\%, CI -1.07 to -0.89 ) lesser in high-risk neonates compared to low-risk neonates. Both these differences were statistically significant with a p-value less than 0.001 (Table 2).

\begin{tabular}{|c|c|c|c|c|c|}
\hline \multirow{2}{*}{ Category } & \multirow{2}{*}{ Mean } & \multirow{2}{*}{$\begin{array}{c}\text { Mean } \\
\text { Difference }\end{array}$} & \multirow{2}{*}{ P-value } & \multicolumn{2}{|c|}{$95 \%$ CI } \\
\hline & & & & Lower & Higher \\
\hline \multicolumn{6}{|c|}{$\mathrm{pO}_{2}$} \\
\hline High risk & 15.23 & \multirow{2}{*}{-4.767} & \multirow{2}{*}{$<0.001$} & \multirow{2}{*}{-5.784} & \multirow{2}{*}{-3.750} \\
\hline Low risk & 20.00 & & & & \\
\hline \multicolumn{6}{|c|}{$\mathrm{pCO}_{2}$} \\
\hline High risk & 60.44 & \multirow{2}{*}{9.919} & \multirow{2}{*}{$<0.001$} & \multirow{2}{*}{8.688} & \multirow{2}{*}{11.150} \\
\hline Low risk & 50.52 & & & & \\
\hline \multicolumn{6}{|c|}{$\mathbf{P h}$} \\
\hline High risk & 7.13 & \multirow{2}{*}{-0.148} & \multirow[b]{2}{*}{$<0.001$} & \multirow{2}{*}{-0.160} & \multirow{2}{*}{-0.135} \\
\hline Low risk & 7.28 & & & & \\
\hline \multicolumn{6}{|c|}{$\mathrm{HCO}_{3-}$} \\
\hline High risk & 16.82 & \multirow{2}{*}{-4.685} & \multirow[b]{2}{*}{$<0.001$} & \multirow{2}{*}{-5.374} & \multirow{2}{*}{-3.995} \\
\hline Low risk & 21.51 & & & & \\
\hline \multicolumn{6}{|c|}{ Base Excess } \\
\hline High risk & -8.58 & \multirow{2}{*}{-4.225} & \multirow[b]{2}{*}{$<0.001$} & \multirow{2}{*}{-4.786} & \multirow{2}{*}{-3.663} \\
\hline Low risk & -4.35 & & & & \\
\hline
\end{tabular}

Table 3. Comparison of ABG (Arterial Blood Gas)

Parameters between High-Risk and Low-Risk Pregnancies $(N=150)$

The arterial $\mathrm{pCO}_{2}$ was higher and all the other parameters including $\mathrm{pH}, \mathrm{pO}_{2}, \mathrm{HCO}_{3}$ - and base excess were lower in highrisk group neonates. All these differences were statistically significant with a p-value of less than 0.01 . The corresponding mean differences and their 95\% Confidence Interval were shown in Table 3.

\begin{tabular}{|c|c|c|c|c|}
\hline \multirow{2}{*}{ Parameters } & \multicolumn{2}{|c|}{ High-Risk Group } & \multicolumn{2}{c|}{ Low-Risk Group } \\
\cline { 2 - 5 } & $\begin{array}{c}\text { Correlation } \\
\text { coefficient } \\
\text { (r) }\end{array}$ & P-value & $\begin{array}{c}\text { Correlation } \\
\text { coefficient } \\
\text { (r) }\end{array}$ & P-value \\
\hline $\begin{array}{c}\text { Apgar score 1 } \\
\text { minute- pH }\end{array}$ & 0.391 & 0.001 & 0.325 & 0.004 \\
\hline $\begin{array}{c}\text { Apgar score 1 } \\
\text { minute-p0 }\end{array}$ & 0.388 & 0.001 & 0.190 & 0.098 \\
\hline $\begin{array}{c}\text { Apgar score 1 } \\
\text { minute- BE }\end{array}$ & 0.341 & 0.003 & 0.129 & 0.264 \\
\hline $\begin{array}{c}\text { Apgar score } \\
\text { minute- pCO }\end{array}$ & 0.243 & 0.039 & 0.173 & 0.061 \\
\hline $\begin{array}{c}\text { Apgar score 1 } \\
\text { minute- } \mathrm{HCO}_{3-}\end{array}$ & 0.137 & 0.246 & 0.164 & 0.155 \\
\hline
\end{tabular}

Table 4. Comparison of Correlation of 1 Minute Apgar Score and ABG Parameters in High-Risk and Low-Risk Pregnancies $(N=150)$

There were statistically significant $(\mathrm{p}<0.05$ ) weak positive correlation $(\mathrm{r}=0.2-0.4)$ between 1 min Apgar score 
and $\mathrm{pH}, \mathrm{pO}_{2}, \mathrm{pCO}_{2}$ and $\mathrm{BE}$ (Base Excess) in high-risk pregnancy, while in low-risk pregnancy there was statistically significant weak positive correlation between 1 min Apgar score and pH only (Table 4).

\begin{tabular}{|c|c|c|c|c|}
\hline \multirow[b]{2}{*}{ Parameters } & \multicolumn{2}{|c|}{ High-Risk Group } & \multicolumn{2}{|c|}{ Low-Risk Group } \\
\hline & \begin{tabular}{|c|} 
Correlation \\
Coefficient
\end{tabular} & P-value & \begin{tabular}{|c|} 
Correlation \\
Coefficient
\end{tabular} & P-value \\
\hline $\begin{array}{l}\text { Apgar score at } \\
5 \text { minutes- } \mathrm{pH}\end{array}$ & 0.277 & 0.018 & 0.133 & 0.062 \\
\hline $\begin{array}{l}\text { Apgar score at } \\
5 \text { minutes- } \mathrm{pO}_{2} \\
\end{array}$ & 0.022 & 0.852 & 0.041 & 0.726 \\
\hline $\begin{array}{c}\text { Apgar score at } \\
5 \text { minutes- BE }\end{array}$ & 0.147 & 0.216 & 0.057 & 0.620 \\
\hline $\begin{array}{c}\text { Apgar Score at } \\
5 \text { minutes- } \\
\text { pCO }_{2} \\
\end{array}$ & 0.139 & 0.242 & 0.124 & 0.284 \\
\hline $\begin{array}{c}\text { Apgar score at } \\
5 \text { minutes- } \\
\mathrm{HCO}_{3-}\end{array}$ & 0.099 & 0.402 & 0.186 & 0.068 \\
\hline $\begin{array}{l}\text { Table 5. Com } \\
\text { Score and A }\end{array}$ & $\begin{array}{r}\text { G Paran } \\
\text { Preg }\end{array}$ & sin & $\begin{array}{l}\text {-Risk a } \\
\text { 50) }\end{array}$ & $\begin{array}{l}\text { Apgar } \\
\text { w-Risk }\end{array}$ \\
\hline
\end{tabular}

There was a statistically significant weak positive correlation $(\mathrm{r}=0.2-0.4)$ between 5 min APGAR score and $\mathrm{pH}$ in high risk pregnancy, while in low risk pregnancy there were no statistically significant correlation between $5 \mathrm{~min}$ APGAR score and any of the umbilical artery blood gas parameters (Table 5).

\section{DISCUSSION}

This was an analytical comparative study done during June 2016 to May 2017 at Sri Lakshmi Narayana Institute of Medical Sciences, Puducherry. Target population includes all term pregnant mothers with their newborn. Study population was newborns delivered to mothers with risk factors based on inclusion and exclusion criteria. This study was done to correlate Apgar score and Umbilical arterial blood gas parameters in high- and low-risk newborns at birth. This may be the first Indian study to observe the correlation between Apgar score and Umbilical arterial blood gas parameters.

\section{Demography}

In our study, 150 pregnancies were enrolled. Out of them 63 (42\%) were primigravida and 87 (58\%) were multigravida. High-risk and low-risk pregnancies were in $73(45.2 \%)$ and 77 (64.9\%) respectively, whereas Kacho MA et $\mathrm{al}^{7}$ also divided Demographic variables into high-risk and low-risk groups.

\section{High Risk Factors}

In our study, high-risk group included pregnancy with one of the risk factors as mentioned earlier. This risk factor inclusion criterion was similar to studies done by Kacho MA et $\mathrm{al}^{7}$ and Goldaber KG et al. ${ }^{8}$

The predominant risk factors seen in our study according to frequency are as follows: Abnormal FHR, MSAF and Emergency LSCS. This was partially similar to study done by Kacho MA et al,7 which also showed Emergency LSCS as the most common risk factor followed by MSAF and PROM.

In our study, the least common risk factors were multiple pregnancies and post-dated pregnancy. This finding was similar to study done by Kacho MA et al, ${ }^{7}$ which showed multiple pregnancies as of the least risk factors.

\section{Mode of Delivery}

In our study, normal vaginal delivery was the predominant mode of delivery in both high-risk $(45.2 \%)$ and low-risk groups (64.9\%). Other modalities of deliveries like LSCS, Vacuum and Forceps are also almost similar in both high-risk and low-risk group. But in low-risk group they are due to maternal indications like poor maternal effort, failed induction and maternal concern towards safe confinement. There was also no statistical significant difference between high-risk and low-risk pregnancies in the various modes of deliveries ( $p>0.05$ ). This may be the first study to compare the mode of deliveries between high- and low-risk groups. None of the studies compared the mode of deliveries between high- and low-risk groups. But Rahmanian $\mathrm{K}$ et $\mathrm{al}^{9}$ compared mode of deliveries (Elective Caesarean Section and Normal Vaginal Deliveries) with 5 mins Apgar score and found that there were no significant difference between two mode of deliveries.

\section{Gender}

In our study, 78 (52\%) were male babies and 72 (48\%) were female babies. There was no statistically significant difference in gender of the babies between high-risk and low-risk group ( $p>0.05$ ). Similar observations were seen in Kacho MA et $\mathrm{al}^{7}$ study.

\section{Birth Weight}

In our study, all 16 (10.7\%) low birth weight ( $<2.5 \mathrm{kgs})$ newborns belonged to high-risk group and the mean birth weight was lower in high-risk group compared to low-risk group and this observation was in concordance with Kacho MA et al $^{7}$ study.

\section{Gestational Age}

Our study was done in term babies only. Similar observations were seen in Kacho MA et al, ${ }^{7}$ Anyaegbunam A et al, ${ }^{10}$ Locatelli $\mathrm{A}$ et $\mathrm{al}^{11}$ and Modarressnejad $\mathrm{V}$ et $\mathrm{al}^{5}$ studies, whereas Manganaro $\mathrm{R}$ et $\mathrm{al}^{12}$ studied in both term and preterm infants.

\section{Advance Resuscitation}

Out of 73 babies who were delivered to high-risk mothers, 5 $(6.8 \%)$ required advanced resuscitation in our study which was almost similar to Kacho MA et $\mathrm{al}^{7}$ study who observed 3 (6.12\%) high-risk newborns required advanced resuscitation. In this study, none of the low-risk group newborns required advanced resuscitation which was in concordance with Kacho MA et $\mathrm{al}^{7}$ study.

In our study, we found that there was a significant difference between high-risk and low-risk babies who required advanced resuscitation which was dissimilar with Kacho MA et al $^{7}$ study who showed no significant difference between high-risk and low-risk babies who required advanced resuscitation. 


\section{NICU Admission}

In our study 18 (12\%) babies required NICU admission, all of which belonged to high-risk group. None of the babies in lowrisk group required NICU admission and this difference was statistically significant $(\mathrm{p}<0.05)$. Out of 18 NICU admissions 7 (38.9\%) were admitted for respiratory distress, 5 (27.8\%) for post resuscitation care, 4 (22.2\%) for sepsis and 2 (11.1\%) for hypoglycaemia.

In Kacho MA et al ${ }^{7}$ study, 3 (6.12\%) high-risk group babies required NICU admission which was not similar to our study, but no low-risk babies required NICU admission which was same as in our study.

In a study by Manganaro R et al,12 10/613 infants (1.6\%) required NICU admission. Out of them, 7 (70\%) were admitted either for respiratory distress or for birth asphyxia. This finding was similar to our study, where most of the admissions were due to respiratory distress and post resuscitation care $(66.7 \%)$.

Newborns with both abnormal pH and 5 mins Apgar had the highest incidence of NICU admissions, which was seen in Anyaegbunam A et al ${ }^{10}$ study.

\section{Apgar Score \\ In our study, the Mean (SD) Apgar score at 1 and 5 minutes were low in high-risk group compared to low-risk group, which was similar to Kacho MA et $\mathrm{al}^{7}$ study in which there were statistically significant difference in 1 minute and 5 minutes APGAR scores between high-risk and low-risk groups. \\ In a study by Manganaro $\mathrm{R}$ et $\mathrm{al}^{12}$ demonstrated that 1 min Apgar score was more influenced by the mode of delivery and by gestational age and 5 mins Apgar score had a high concordance with metabolic acidaemia. In our study both 1 and 5 mins Apgar scores were not much influenced by mode of delivery, whereas both 1 and 5 mins Apgar scores were influenced by abnormal $\mathrm{pCO}_{2}$ and $\mathrm{HCO}_{3}$-values. \\ Modarressnejad $\mathrm{V}$ et $\mathrm{al}^{5}$ showed that low 1 min Apgar score was significantly related to acidaemia.}

\section{Umbilical Cord Blood Gas Analysis}

In our study Umbilical artery parameters like $\mathrm{pH}, \mathrm{pO}_{2}, \mathrm{pCO}_{2}$ and $\mathrm{HCO}_{3}$ - values are statistically significant between highand low-risk pregnancies which was in concordance with Kacho MA et al7 study, whereas in addition BE was also statistically significant in our study which was not seen in Kacho MA et al ${ }^{7}$ study.

\section{Correlation between Apgar Score and Umbilical Cord Blood Gas Analysis}

In the literature, only few studies (Kacho MA et al, ${ }^{7}$ Manganaro $\mathrm{R}$ et $\mathrm{al}^{12}$ ) had correlated Apgar scores at 1 minute and 5 minutes with Umbilical artery parameters. Kacho MA et $\mathrm{al}^{7}$ showed that significant correlation between Apgar score at 1st and 5th minute and the umbilical cord $\mathrm{pH}$ concluded that a combination of Apgar score and umbilical cord $\mathrm{pH}$ measurement in high-risk pregnant mothers could better detect jeopardised baby, whereas Manganaro $\mathrm{R}$ et $\mathrm{al}^{12}$ observed that low Apgar scores with metabolic acidaemia have the highest incidence of NICU admission and poor neonatal outcome.
Two studies (Fields LM et $\mathrm{al}^{2}$ and Boehm FH et $\mathrm{al}^{13}$ ) had correlated 1 minute Apgar score with Umbilical artery $\mathrm{pH}$ and showed that metabolic acidaemia was seen in $46 \%$ and $87.5 \%$ of newborn babies respectively.

In a study done by Manganaro $\mathrm{R}$ et $\mathrm{al}, 12$ found that metabolic acidaemia is associated with low 5 minutes Apgar score.

The studies by Anyaegbunam A et al, ${ }^{10}$ Locatelli $\mathrm{A}$ et al ${ }^{11}$ and Sykes GS et al ${ }^{14}$ also showed that metabolic acidaemia is associated with low 5 minutes Apgar score.

Studies done by Raafati $\mathrm{SH}$ et $\mathrm{al}^{15}$ Kaveh $\mathrm{M}$ et $\mathrm{al}^{16}$ and Garzoli E et $\mathrm{al}^{17}$ showed that there is no positive correlation between Apgar score and Umbilical artery acidaemia with mode of delivery. In our study, Apgar score and Umbilical artery blood gas values were not influenced by mode of delivery.

Studies done by Gilstrap LC et $\mathrm{al}^{18,19}$ and Honjo S et $\mathrm{al}^{20}$ had correlated umbilical artery acidaemia with abnormal foetal heart rate in the second stage of labour. This is similar to our study, in which $90 \%$ of cases with abnormal heart rate had acidaemic arterial blood gas values.

\section{CONCLUSION}

Our study highlights a correlation between 1 minute Apgar score and umbilical artery blood gas parameters in high-risk pregnancy. So, we recommend assessing umbilical blood gas analysis in neonates born to high-risk mothers to detect metabolic acidaemia earlier.

\section{ACKNOWLEDGEMENTS}

I thank Dr. Manivel Prakash M.D., (Preventive and Social Medicine), for his statistical support in completing this study.

\section{REFERENCES}

[1] Apgar V. A proposal for a new method of evaluation of the newborn infant. Curr Res Anest Analg 1953;32(4):260-7.

[2] Fields LM, Entman SS, Boehm FH. Correlation of the one minute apgar score and the $\mathrm{pH}$ value of umbilical arterial blood. South Med J 1983;76(12):1477-9.

[3] Ross MG, Gala R. Use of umbilical artery base excess: algorithm for the timing of hypoxic injury. Am J Obstet Gynecol 2002;187(1):1-9.

[4] Williams KP, Singh A. The correlation of seizures in newborn infants with significant acidosis at birth with umbilical cord gas values. Obstet Gynecol 2002;100(3):557-60.

[5] Modarressnejad V. Umbilical cord $\mathrm{pH}$ and risk factor for acidaemia in neonates in Kerman. East Mediterr Health J 2005;11(1-2):96-101.

[6] American Academy of pediatrics, American Heart Association. In: Textbook of Neonatal Resuscitation. $5^{\text {th }}$ edn. Kattwinkel J, Short J, (eds). American Academy of Pediatrics. Elk Grove Village, Illinois 2006:1-15.

[7] Kacho MA, Asnafi N, Javadian M, et al. Correlation between umbilical cord $\mathrm{pH}$ and apgar score in highrisk pregnancy. Iran J of Pediatr 2010;20(4):401-6.

[8] Goldaber KG, Gilstrap LC. Correlations between obstetric clinical events and umbilical cord blood acidbase and blood gas values. Clin Obstet Gynecol 1993;36(1):47-59. 
[9] Rahmanian K, Jahromi AS, Rahmanian V, et al. Association of apgar score with delivery mode in the non distress newborns. Online J Biol Sci 2014;14(1):21-5.

[10] Anyaegbunam A, Fleischer A, Whitty J, et al. Association between umbilical artery cord $\mathrm{pH}$, five minute apgar score and neonatal outcome. Gynecol Obstet Invest 1991;32(4):220-3.

[11] Locatelli A, Incerti M, Ghidini A, et al. Factors associated with umbilical artery acidemia in term infants with low apgar score at $5 \mathrm{~min}$. Eur J Obstet Gynecol Reprod Biol 2008;139(2):146-50.

[12] Manganaro R, Mami C, Gemelli M. The validity of the apgar score in the assessment of asphyxia at birth. Eur J Obstet Gynecol Reprod Biol 1994;54(2):99-102.

[13] Boehm FH, Fields LM, Entman SS, et al. Correlation of the one minute apgar score and umbilical cord acidbase status. South Med J 1986;79(4):429-31.

[14] Sykes GS, Molloy PM, Johnson P, et al. Do apgar scores indicate asphyxia? Lancet 1982;1(8270):494-6.
[15] Raafati SH, Borna H, Tehrani FHB, et al. Neonatal apgar scores and umbilical blood gas changes in vaginal delivery and cesarean section: a comparative study. Tehran Univ Med J 2006;64(4):61-8.

[16] Kaveh M, Davari FT, Farahani MS. Apgar score and arterial blood gas in the first hour of birth in neonates. Iran J Pediatr 2004;14(1):27-32.

[17] Garzoli E, Monteleone M, Migliori C, et al. Umbilical acid-base status of term infants: correlation with delivery mode. Pediatr Med Chir 2007;29(4):202-5.

[18] Gilstrap LC, Hauth JC, Toussaint S. Second stage fetal heart rate abnormalities and neonatal acidosis. Obstet Gynecol 1984;63(2):209-13.

[19] Gilstrap LC, Hauth JC, Hankins GD, et al. Second-stage fetal heart rate abnormalities and type of neonatal acidemia. Obstet Gynecol 1987;70(2):191-5.

[20] Honjo S, Yamaguchi M. Umbilical artery blood acidbase analysis and fetal heart rate baseline in the second stage of labor. J Obstet Gynecol Res 2001;27(5):249-54. 